\title{
施設栽培トマトでのタバココナジラミ新系統に対する オンシツツヤコバチの密度抑制効果
}

\author{
松 井 正 春
}

\section{農林水産省野菜・茶業試験業}

\begin{abstract}
Efficiency of Encarsia formosa GAHAN in Suppressing Population Density of Bemisia argentifolii BeLLOws \& PERring on Tomatoes in Plastic Greenhouses. Masaharu MATSUI (National Research Institute of Vegetables, Ornamental Plants and Tea, Ano, Mie 514-23, Japan). Jpn. J. Appl. Entomol. Zool. 39: 25-31 (1995)

To control B. argentifolii on tomatoes in plastic greenhouses, Encarsia formosa $\left(\right.$ EN-STRIP $^{\circledR}$ produced by KOPPERT BV) was released once or three times at about twice the adult density of the whitefly. In control plots, the population density of the whitefly increased progressively to a high level causing sooty mold and irregular ripening of tomato fruits. In the release plots, the population density of the whitefly was held at a lower level and no damage was caused. Non-parasitization mortality of $B$. argentifolii was relatively high and seemed to be caused by host feeding and undetermined mortality factors. E. formosa can survive and reproduce in plastic greenhouses where daily maximum temperatures exceeded $35^{\circ} \mathrm{C}$ for $7-11$ days.

Key words: Encarsia formosa, Bemisia argentifolii, new strain, tomato, damage
\end{abstract}

緒

言

カボチャに白化症 (silverleaf) を起こすタバココナジラ ミ新系統 (以下, 新系統と略す) は, 1986 年頃から米国 フロリダ州で発生し始め (PrICE et al., 1987; BYrNE et al., 1990), 日本でも 1989 年に発生が確認された (大戸, 1990;外間ら，1991)。施設栽培における新系統による被 害は, ヨーロッパではこれまでのところ主としてポイン セチアに限定されているが，日本や米国ではポインセチ ア以外にもトマト等の果菜類で問題となっている。新系 統は，以前から知られていた旧系統と生理生態的性質が 多くの点で異なり (大泰司ら，1992；松井，1993), PERRING et al. (1993)は, 両系統の交尾実験とアイソザイ ムや DNA 分析の結果から, 新系統と旧系統とは別種” であると報告し, 新系統に対する防除戦略として, 最適 の天敵を見出し導入することが重要であると強調した。

新系統を防除するために，オンシッコナジラミ Trialeurodes vaporariorum (WESTWOOD) の有力な天敵であるオ ンシツツヤコバチ Encarsia formosa GAHAN (以下, E. formosa と略す)を用いた試験がポインセチアで行われ，多数回
(毎週) 放飼によって高い防除効果が得られたことが報告 されている (BenuzZI et al., 1990; PARrella et al., 1991)。 しかし, 新系統の幼虫体内での E. formosa の死亡率が極 めて高いこと (BOISCLAIR et al., 1990), 新系統の幼虫体内 での E. formosa の発育期間がオンシツコナジラミ幼虫で の場合よりも長いこと (SZABO et al., 1993) などの問題も 指摘されている。また施設栽培トマトでの新系統に対す る E. formosa の密度抑制効果に関する報告について, こ れまでに著者が予備試験として小型ガラス室でポット植 えトマトを用いて行ったもの(松井, 1992a) 以外には殆 ど見当らない。

そこで，本論文においては，更に規模の大きいビニー ルハウスを用い，2 作期に栽培したトマトで新系統に対 し E. formosa を少数回放飼し, 密度抑制効果, 被害防止 効果, 死亡要因, 気温の影響等について調査し, 本寄生 蜂の密度抑制能力を調べたので，その概要を報告する。

本文に入るに先立ち, 新系統の新しい学名に関してご 教示いただいた九州大学農学部の梶田泰司博士に感謝申 し上げる。

1993 年 12 月 14 日受領 (Received 14 December 1993)

1994 年 7 月 23 日登載決定 (Accepted 23 July 1994)

1) 最近, 新系統は Bemisia argentifolii BeLLOWS \& PERRING の名で新種として記載されたが (BeLLows et al., 1994), 本種の和名が未 定のために，本稿では「タバココナジラミ新系統」と従来の呼称を使用する. 


\section{材料および方法}

1. 供試したタバココナジラミ新系統および $\boldsymbol{E}$. formosa

農林水産省野菜・茶業試験場 (三重県安濃町) 内の施設 栽培ナスから採集した新系統個体群を, $25^{\circ} \mathrm{C}, 16$ 時間明 8 時間暗条件の室内でキャベツ葉を用いて累代飼育し, カボチャに接種して白化症を起こすことを確認し，新系 統であることを確かめた後に供試した。E. formosaは, KOPPERT 社でオンシツコナジラミを用いて生産され, 厚 紙(カード)に張り付けられた状態のマミー(商品名：ENSTRIP $\left.{ }^{\circledR}\right)$ を供試した。

\section{2. 放飼試験}

トマトで発生する新系統に対する E. formosa の密度抑 制効果を調査するために，異なる 2 作期にトマトを栽培 し, E. formosaの放飼試験を行った。すなわち，放飼試験 I は 1992 年 8 月定植のトマトで, 放飼試験 II は 1993 年 4 月定植のもので行った。トマト品種は瑞栄を用い, 定 植は株間 $45 \mathrm{~cm}$, 畧間 $1 \mathrm{~m}$ の間隔で行った。両放飼試 験ともそれぞれ 3 棟のビニールハウス (各 $50 \mathrm{~m}^{2}$ )を使用 し, 側空には白色寒冷紗 (網目 $1 \mathrm{~mm}$ ) を張った。定植翌 日に新系統の成虫を株当たり 5 頭接種した。E. formosa 無放飼区における本寄生蜂の活動を防止するために，放 飼試験 I では 9 月 15 日および 10 月 15 日に, 放飼試験 II では 7 月 4 日にDMTP乳剤 3,000 倍液を各 1 lずつ散 布した。トマトの下葉の切除は, 枯葉や不健全葉など必 要最小限にとどめた。芯止めは放飼試験 I では 10 月下 旬に，放飼試験 II では 6 月中旬に行い, この時の株当 たり葉数はそれぞれ 25〜30枚であった。温度調節は,

各棟とも $30^{\circ} \mathrm{C}$ 以上で換気扇により強制換気して行っ た。また, 放飼試験 I の 3 回放飼区および無放飼区に ついては, 11 月 25 日以降石油暖房機により $10^{\circ} \mathrm{C}$ 以上 に加温した。ビニールハウス内の気温は, 地表約 $30 \mathrm{~cm}$ に遮光して設置した自記温度計を用いて測定した。

新系統に対する E. formosa の放飼密度および放飼回数 については，オンシツコナジラミに対する E. formosa の 放飼試験を参考にして行った。すなわち，オンシツコナ ジラミの成虫密度が株当たり 0.5 頭になった時に株当た り 1 頭の E. formosa 2 週間間隔で 3 回放飼することに よって放飼効果が上がるとされている(矢野・腰原, 1984; YANO, 1987)。そこで, 今回の試験では新系統の成 虫密度に対して 2 倍の E. formosa 1 回または 3 回放飼 してその効果を見た。

放飼試験 I の試験区としては, E. formosa の 1 回放飼
Table 1. Date and number of E. formosa released, and density of $B$. argentifolii on date of parasitoid release for first time in each experiment

\begin{tabular}{lccc}
\hline \multicolumn{1}{c}{ Plot } & $\begin{array}{c}\text { Date of } \\
\text { E. formosa } \\
\text { release }\end{array}$ & $\begin{array}{c}\text { Number of } \\
\text { E. formosa } \\
\text { released/plant }\end{array}$ & $\begin{array}{c}\text { Density of } \\
\text { B. argentifolii } \\
\text { adults/plant }\end{array}$ \\
\hline $\begin{array}{l}\text { Experiment I) } \\
\text { One release } \\
\text { Three releases }\end{array}$ & $\begin{array}{c}\text { 4/IX } \\
\text { 4/IX, 17/IX, }\end{array}$ & ca.10 & 6.1 \\
Control & $9 / \mathrm{X}$ & ca.10 & 6.3 \\
\hline Experiment II) & - & 0 & 5.5 \\
Three releases (A) & $20 / \mathrm{IV}, 30 / \mathrm{IV}$, & & \\
& $11 / \mathrm{V}$ & ca.4 & 2.0 \\
Three releases (B) & $20 / \mathrm{IV}, 16 / \mathrm{VI}$, & & \\
& $23 / \mathrm{VI}$ & ca.4 & 2.2 \\
Control & - & 0 & 1.3 \\
\hline
\end{tabular}

区，3回放飼区および無放飼区を設けた。放飼試験 II で は, E. formosa の放飼時期を変えた 2 種類の 3 回放飼区 (A区および B区) および無放飼区を設けた。E.formosa の 放飼は, 所定量(羽化率で補正)のマミーカードをトマト の葉柄に吊り下げて行った。各放飼区の E. formosa 放飼 日と放飼数および新系統の成虫の株当たり密度を Table 1 に示した。新系統の密度は, 各試験において第 1 回目 の E. formosa 放飼直前に各区 20 株について見取り調査 した值から求めた。

\section{3. 調查方法}

ハウス内を 4 等分し，それぞれの中心付近に 1 枚ず つ, 計 4 枚の黄色粘着板 $(12.5 \mathrm{~cm} \times 7 \mathrm{~cm}$, 両面粘着; Whitmire Res. Lab. Inc. 製) を草冠から約 $30 \mathrm{~cm}$ 下の位置 に設置し，それらを概ね1 週間間隔で交換して新系統の 成虫の誘殺数を調査した。また 10〜15日間隔で, トマ 卜葉上の新系統の龄期別生存幼虫数, 死亡幼虫数および マミー数をサンプリング後, 実体顕微鏡 (10１5 倍) を 用いて調查した。なお 4 齢幼虫については, 未褐変の個 体をピンセットで挟んで潰し, 体内に E. formosa 幼虫が 存在するか否かを調査した。この調査は原則として各区 12 株について, 各株とも同一の連続する 3 葉位から 1 小葉ずつ, 合計 36 小葉をサンプリングして行った。な お, 調査対象葉位は, 調査日ごとに幼虫の発育状況を戋 場で観察し, 老齢幼虫の存在比率の高い葉位とした。新 系統による被害については, 着色異常果の比率および果 実でのすす病発生率を調査した。 
結果および考察

\section{1. 黄色粘着トラップによるタバココナジラミ新系統 の成虫誘殺数}

放飼試験 I での黄色粘着トラップによる新系統の成虫 誘殺数は，無放飼区では急激に増加し，12 月に入ると トラップ当たり誘殺数は日当たり 100 頭を越えた。一 方, 放飼区の誘殺数は，1 回放飼区，3回放飼区とも類 似した傾向を示し，12月に入っても 1 回放飼区で最高 4.3 頭, 3 回放飼区で最高 6.0 頭と低水準で推移した (Fig. 1)。

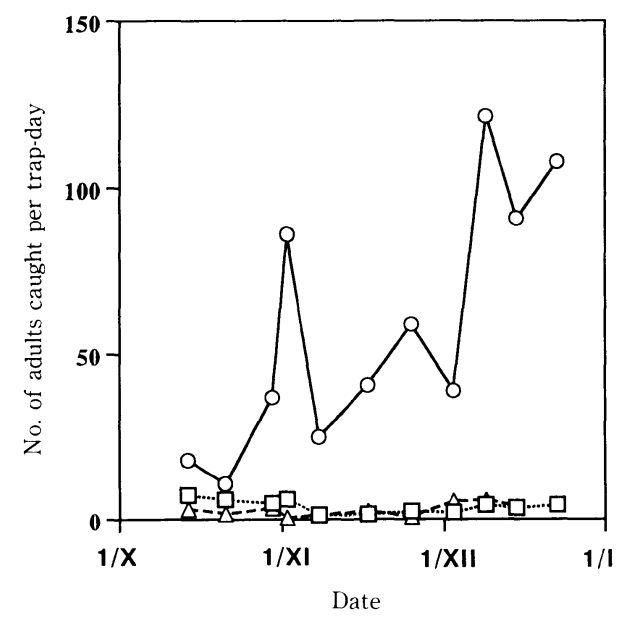

Fig. 1. Number of $B$. argentifolii adults caught with yellow sticky traps in experiment I. $O, \square$ and $\Delta$ mean control, one release and three releases, respectively.

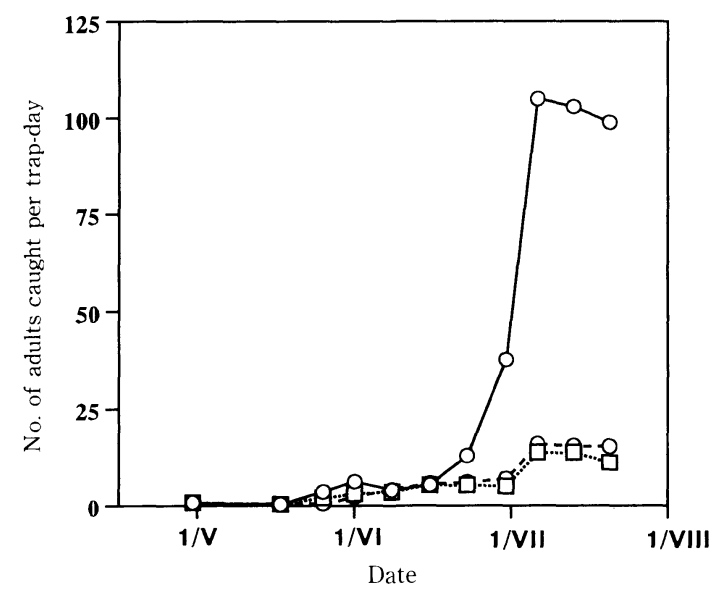

Fig. 2. Number of $B$. argentifolii adults caught with yellow sticky traps in experiment II. $O, \square$ and $\Delta$ mean control, three release (A) and three releases (B), respectively.
放飼試験 II における新系統の成虫誘殺数は，6 月中 旬までは無放飼区も放飼区と同様に低水準で推移した。 しかし，それ以後は無放飼区の誘殺数が急增し，7月に 入るとトラップ当たり日当たり 100 頭を越えた。一方, 放飼区は $\mathrm{A}, \mathrm{B}$ 両区とも 7 月以降も $11 \sim 16$ 頭の水準で 推移した (Fig. 2)。

2. トマト葉上のタバココナジラミ新系統の幼虫密度 放飼試験 I における小葉当たり幼虫数 (1〜4 齢) は, 無放飼区では次第に増加し, 10 月下旬には 98 頭, 11 月 末には 163 頭，12 月末には 845 頭に達した。放飼区で

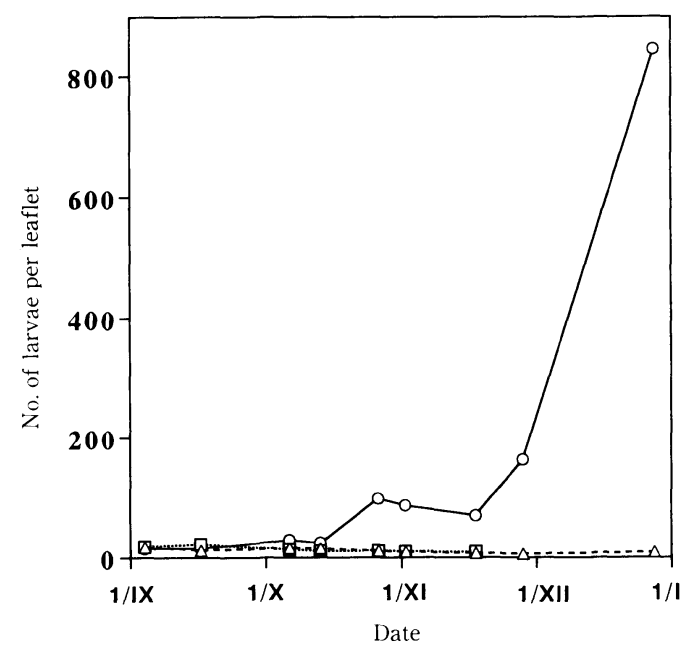

Fig. 3. Number of larvae of $B$. argentifolii per leaflet on tomato plants in experiment I. The symbol meanings are the same as in Fig. 1.

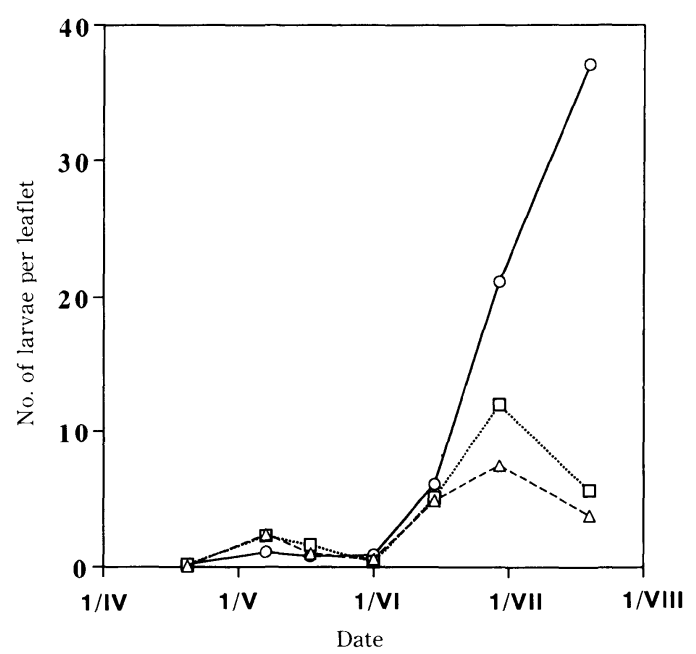

Fig. 4. Number of larvae of $B$. argentifolii per leaflet on tomato plants in experiment II. The symbol meanings are the same as in Fig. 2. 
の小葉当たり幼虫数は無放飼区とは対照的に，9月初旬 以降低密度で推移した。放飼区の最高密度は，10月下 旬には小葉当たり 12 頭，11月下旬には 6 頭，12月下 旬には 9 頭であった(Fig. 3)。

放飼試験 II における小葉当たり幼虫数は, 黄色粘着 トラップによる成虫数の推移と同様，6月中旬までは放 飼区と無放飼区とで差は見られなかった。しかし，無放 飼区では 6 月下旬以降小葉当たり 21〜37 頭と次第に増 加したのに対して，この時期の放飼区 (A)では小葉当た り 6〜12 頭, 放飼区 (B) では約 8 頭の水準で推移した (Fig. 4)。

今回の 2 作期における放飼試験での黄色粘着トラップ による新系統の誘殺数は，オンシツコナジラミに対する E. formosa 放飼の場合のオンシツコナジラミの誘殺数 (YANO, 1987) と比較して，トラップ面積および誘殺日数 の差を補正してみると同等以下の水準であった。しか し, 幼虫密度で見ると, 今回の試験における放飼区の小 葉当たり新系統の幼虫密度は最高値で 6〜12 頭であり, 仮に葉当たり小葉数を 7〜9枚とすると葉当たり幼虫密 度は 42〜108 頭となる。一方，オンシッコナジラミに $E$ formosa を放飼した場合 (矢野，1988) では，放飼区の株当 たりオンシッコナジラミ幼虫密度の最高が 400 ～ 600 頭 程度とみられるので，トマトの 1 株当たり葉数を 20 ～ 30 枚とすると, 葉当たりでは 20－30頭と推定され，上 記の新系統の幼虫密度はこれと比較して 3 4 倍の水準 であったと考えられる。

以上のように，施設栽培トマトに発生する新系統に対 してその成虫密度の 2 倍程度の E. formosa を放飼するこ とにより，新系統の密度を一定の水準以下に継続的に抑 制することができた。しかし，その水準はオンシツコナ ジラミにおける場合よりもやや高く，その原因として $E$. formosa が新系統よりもオンシッコナジラミに寄生しやす い傾向 (BOISCLAIR et al., 1990; HENTER et al., 1993) がある ことと関係しているのかもしれない。

放飼試験 I では，E. formosa を 9 月上旬に 1 回放飼し ただけでも，12 月下旬まで良好な密度抑制効果が認め られた。このことは, オンシッコナジラミで増殖され放 飼された E. formosa が新系統で世代を繰り返し，新系統 の幼虫に効果的に寄生できたことを示している。 HENTER et al. (1993)は，新系統で累代飼育したE. formosa がオンシツコナジラミよりも新系統に対して産卵行動を し易いと報告している。一方，新系統で飼育された $E$. formosaは体サイズが小さく, 卵巣小管が少ない(BOISCLAIR et al., 1990) などの短所もあるが，今回の放飼試験で特

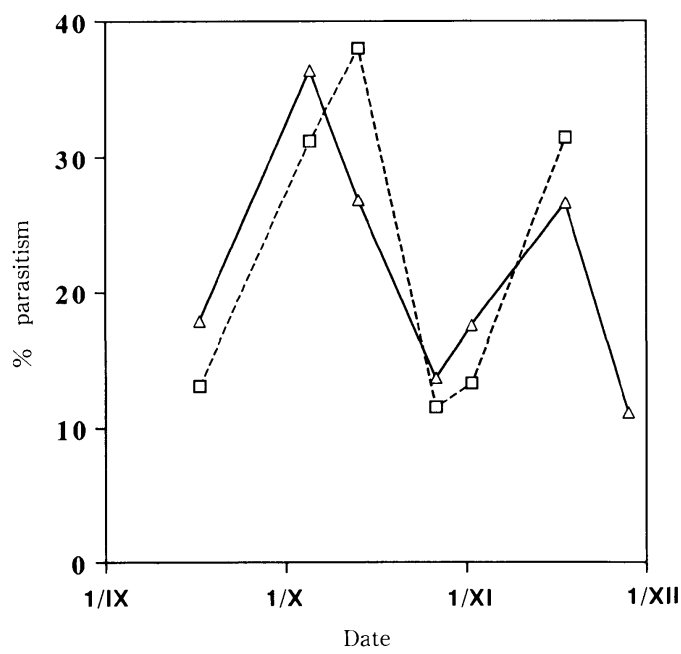

Fig. 5. Percentage of parasitism of 4th instar larvae of $B$. argentifolii by $E$. formosa in experiment $I$. The symbol meanings are the same as in Fig. 1. Percentage of parasitism $=\{$ (number of parasitized larvae $) /($ number of parasitized larvae + number of living 4 th instar larvae) $\} \times$ 100.

に防除上支障を来たさなかったことから，放飼用の $E$ formosa はオンシツコナジラミで堌殖したもので差し支え ないと考えられる。

3. E. formosa の寄生率とタバココナジラミ新系統 の幼虫の死亡率

マミー化した個体と未褐変であるが体内に E. formosa 幼虫が確認された 4 齢幼虫を合せて被寄生幼虫とし, 寄 生率 $(P)$ を次式によって計算した。すなわち,

$$
P(\%)=\frac{L_{\mathrm{p}}}{L_{\mathrm{P}}+L_{4}} \times 100
$$

ただし， $L_{\mathrm{P}}$ は被寄生幼虫数， $L_{4}$ は健全 4 龄幼虫数であ る。放飼試験 I における寄生率を見ると，1 回および 3 回放飼区でそれぞれ $11 〜 36 \%$ および 12 38\% と同様の 傾向を示した(Fig. 5)。放飼試験 II におけるE. formosaの 寄生率は, 放飼区 (A) では 6 月 28 日には $34.4 \%, 7$ 月 19 日には $51.6 \%$, 放飼区 (B) では 6 月 28 日には $17.8 \%, 7$ 月 19 日には $44.4 \%$ であった。新系統の 4 龄生存幼虫体 内に E. formosa の卵あるいは若齢幼虫が寄生していた場 合にはそれらの検出が困難であるため見落している可能 性があるので, これらの寄生率の值は過小評価されてい ると推察される。

新系統は 3,4 齢幼虫期に E. formosa の寄生以外の死亡 を受けることがしばしば観察された。そこで, E. formosa 
の寄生が認められなかった 3,4 齢の死亡幼虫の死亡率 (D) を次式によって計算した。すなわち,

$$
D(\%)=\frac{L_{\mathrm{d}}}{L_{\mathrm{d}}+L_{\mathrm{p}}+L_{3+4}} \times 100
$$

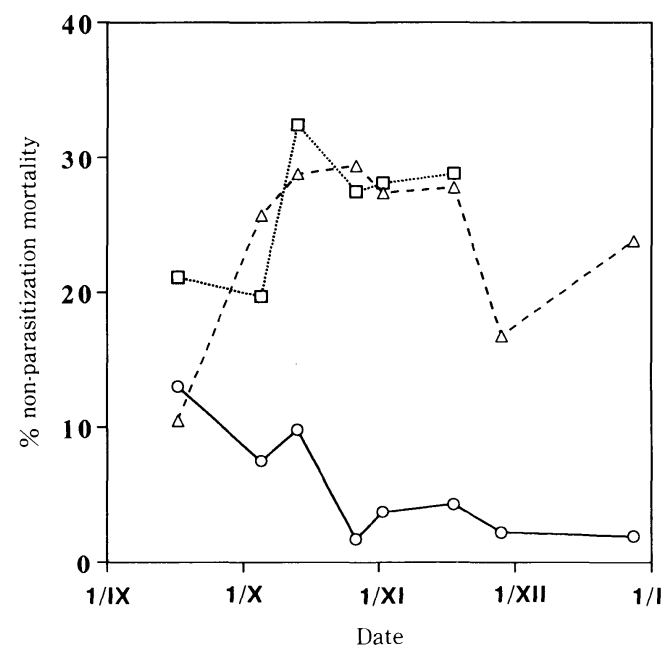

Fig. 6. Non-parasitization mortality of 3rd and 4th instar larvae of B. argentifolii in experiment I. The symbol meanings are the same as in Fig. 1 . The $\%$ mortality= $\{$ (number of dead larvae)/(number of dead larvae + number of parasitized larvae+living unparasitized larvae) $\} \times 100$

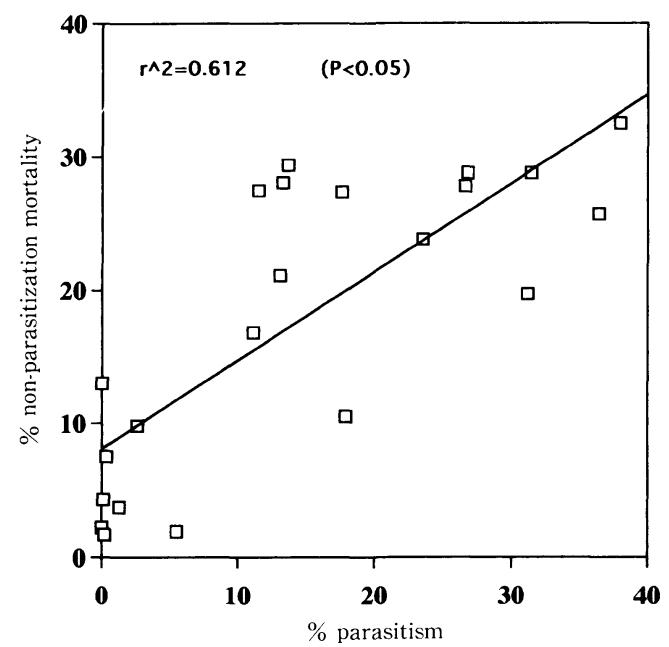

Fig. 7. Relationship between percentage of parasitism of 4th instar larvae by $E$. formosa and non-parasitization mortality of $3 \mathrm{rd}$ and $4 \mathrm{th}$ instar larvae of $B$. argentifolii in experiment I.
ただし， $L_{\mathrm{d}}$ は寄生以外の要因による 3,4 齢死亡幼虫 数, $L_{\mathrm{p}}$ は被寄生幼虫数, $L_{3+4}$ は健全 3,4 齢幼虫数であ る。

放飼試験 I で 3，4 齢幼虫の寄生以外の要因による死 亡率は，放飼区では奇生率が $30 \%$ 以上に上昇した 10 月 以降高くなり，無放飼区と比較して明らかな差が見られ た (Fig. 6)。

寄生が確認されなかった新系統の幼虫の死亡要因を知 る手がかりとして, 調査日ごとの寄生率と寄生以外の要 因による 3,4 齢幼虫の死亡率との関係を調べた。その 結果, 両者の間には統計的に有意な正の相関が認められ た $\left(r^{2}=0.612, p<0.05\right)($ Fig. 7)。このことから, 新系統の 奇生以外の要因による死亡について E. formosa の介在が 推定された。梶田 (1993) は, 新系統の 4 齢幼虫に対す るオンシッッヤコバチの寄主体液掑取 (host feeding) の頻 度は寄主密度の増加に対して飽和型の反応を示すことを 観察している。寄主体液摂取された幼虫のその後の経過 を観察すると死亡する例が多い (松井，未発表)ことか ら, 体内に E. formosa が確認されなかった新系統の幼虫 の高い死亡率は, 大部分寄主体液摄取による死亡と推察 される。以上のように, 本寄生蜂の新系統の密度抑制要 因として, 寄生以外の幼虫期の死亡も重要であることが 推察された。

ビニールハウス内の気温の推移を見ると, 放飼試験 I では E. formosa 放飼後の 1992 年 9 月上旬から 10 月中旬 までの最高気温は $36.4^{\circ} \mathrm{C}, 35^{\circ} \mathrm{C}$ 以上の日数は 7 日間で あった。また, 放飼試験 II の 1993 年 6 月上旬から試験 終了時 (7 月中旬) までは最高気温は $39.8^{\circ} \mathrm{C}, 35^{\circ} \mathrm{C}$ 以上 の日数は 11 日間であった。両放飼試験で気温の高い時 期にも E. formosa の寄生が見られたことから, 本寄生蜂 は1 日の最高気温がこの程度となる变温条件下でも生存 し，かつ発育することができ，活発な寄生活動性を維持 できたものと考えられる。なお，新系統は高温条件に比 較的強く, $30^{\circ} \mathrm{C} 18$ 時間 $35^{\circ} \mathrm{C} 6$ 時間では羽化率に影 響しないが, $30^{\circ} \mathrm{C} 20$ 時間 $40^{\circ} \mathrm{C} 4$ 時間では生育遅延 が見られ羽化率が低下するという(河名・福田，私信)。 放飼試験 I で 9 月に無放飼区の 3,4 齢幼虫の死亡率が やや高かった (Fig. 6) のは, 高温による死亡のためで あったとも考えられる。

\section{4. 着色異常症およびすす病の発生}

放飼試験 Iにおいては, トマト果実の着色異常症は, 3 回放飼区では全く発生せず, 無放飼区では 12 月初旬 から見られ始め, 12 月下旬に多発した。新系統の排泄 物に生ずる果実上のすす病は, 無放飼区では 12 月初旬 


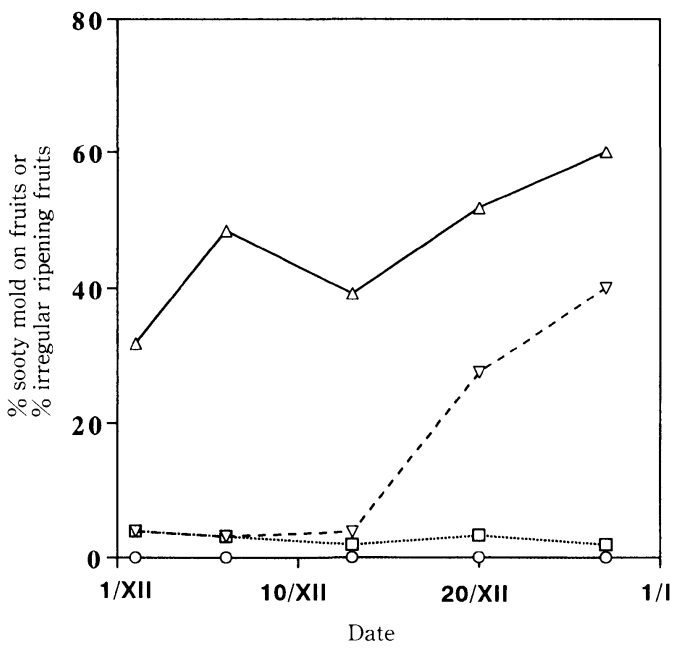

Fig. 8. Percentage of infection by sooty mold and occurrence of irregular ripening of tomato fruits caused by infestation of $B$. argentifolii in experiment I. $\Delta$ and $\square$ indicate the percentage of infection by sooty mold on fruits in the control and three-release plots, respectively. $\nabla$ and $\bigcirc$ indicate the occurrence of irregular ripening of tomato fruits in the control and three-release plots, respectively.

以降継続して多発したが, 3 回放飼区では極く軽いもの が僅かに生じた程度であった (Fig. 8)。ちなみに，同放飼 区の 9 月以降の小葉当たり新系統の幼虫数 (1４ 齢) は，9月には 13〜22 頭，10月には 12～16 頭，11 月に は 6 10 頭，12 月には 9 頭程度であった。

放飼試験 II における 7 月 20 日の調査では, 極く軽微 のすす病が放飼区 (A) では 4.9\% (調查果実数 102 個), 放飼区 (B) では $1.8 \%$ (同 54 個) 見られたのに対し, 無放 飼区では著しい污れを含めて $40.5 \%$ (同 131 個) と多発し た。着色異常果はいずれの区でも見られなかった。無放 飼区でも着色異常果が見られなかったのは, 新系統の発 生が遅れ, 果実が肥大し収穫終了時期に近い 7 月に入っ てようやく幼虫密度が小葉当たり 30 頭を超えたためと 思われる。

トマト果実に着色異常症が発生し始める時の新系統の 幼虫密度は, 1 4 齢幼虫数で葉当たり 100〜300 頭 (西 東·尾崎, 1991), あるいは第 1 果房の直下葉の 3, 4 齢 幼虫数が葉当たり約 80 頭以上 (松井, 1992b) であるこ とが知られている。放飼試験 $\mathrm{I}$ の放飼区では着色異常果 が生じなかったが，これは 1 葉当たりの小葉数を 7〜9 枚として計算すると, 幼虫密度が上記の着色異常症が発 生し始める密度に近い值となる場合もあったが, 概ねそ れ以下であったためと推察される。

施設栽培トマトの新系統の防除に E. formosa を放飼し
た今回の試験で, 新系統の成虫密度の約 2 倍の E. formosa を放飼すれば，高温時であっても着色異常果等の実害を 生じない程度の防除効果は期待できることが明らかに なった。また，新系統がオンシツコナジラミと混発した 場合に，E． formosa は前者を選好する傾向を示すが (BOISCLAIR et al., 1990; 松井・中島, 1991), 両種コナジ ラミの発生初期に E. formosa をコナジラミ成虫密度の 2 倍以上放飼す机ば, 混発条件でも新系統の密度を低水準 に抑制し得る(松井, 未発表)。しかし, 実際の生産現場 では，果実の成熟に伴って下葉が順次切除され一緒にマ ミーも除去されること, 八ウス内温度が更に高くなる場 合が想定されることなど今回の試験と異なる条件も存在 する。従って，E. formosa によって安定的な密度抑制効 果を得るためには, E. formosaの虫質管理を行ってその能 力を十分に発揮させるだけでなく, 放飼回数の増加, 無 害虫苗の定植, 初期密度低減および侵入防止対策, 選択 的農薬の使用等の各種防除手段を組み合わせた総合防除 体系の中でその利用を図っていく必要がある。

\section{摘要}

ビニールハウス栽培トマトでのタバココナジラミ新系 統に対するオンシツッヤコバチ Encarsia formosa の密度抑 制効果を知るために，放飼時における新系統の成虫密度 の約 2 倍の E. formosa マミーを 1 回又は 3 回放飼した。 その結果, いずれの放飼区においても, 新系統の密度が 抑制され，すす病及び着色異常果の発生も殆どなかっ た。また，E.formosaの新系統に対する密度抑制要因とし て, 寄生並びに未褐変状態での原因不明の死亡および寄 主体液摂取による死亡が推察された。E. formosa は 1 日 の最高気温が $35 \sim 40^{\circ} \mathrm{C}$ となる施設内でも有効であっ た。以上のことから，E. formosaは，我が国における施設 栽培トマトのタバココナジラミ新系統の生物的防除素材 として有用であると考えられる。

\section{引用 文 献}

Bellows, T.S. JR., T.M. Perring, R.J. Gill and D.H. Headrick (1994) Description of a species of Bemisia (Homoptera: Aleyrodidae). Ann. Entomol. Soc. Am. 87: 195-206.

Benuzzi, M., G. Nicoli and G. Manzaroli (1990) Biological control of Bemisia tabaci (GENN.) and Trialeurodes vaporariorum (WESTw.) by Encarsia formosa GAHAN on poinsettia. SROP/ WPRS Bull. 13(5): 27-31.

Boisclair, J., G.J. Brueren and J.C. van Lenteren (1990) Can Bemisia labaci be controlled with Encarsia formosa? SROP/WPRS 
Bull. 13(5): 32-35

Byrne, D., T.S. Bellows, JR. and M.P. Parrella (1990) Whiteflies in agricultural systems. In: Whiteflies: their Bionomics, Pest Stutus and Management. (D. Gerung ed.), Hants, UK: Intercept Ltd., pp. 227-261.

Henter, H.J., P.C. Luttikhuizen, J.W. Visser and J.C. van LENTEREN (1993) Variation host use in Encarsia formosa. IOBC/WPRS Bull. 16(2): 67-70.

外間也子・松井正春 ·河野伸二・渡嘉敷唯助 (1991) タバココ ナジラミによるカボチャの白化症 (シルバーリーフ)の発 生. 平成 3 年度植物病理学会 p. 216 [講要].

梶田泰司 (1993) Encarsia formosa と Encarsia transvena の hostfeeding と寄生に及ぼすタバココナジラミの発育齢期と密度 の影響. 九病虫研会報 39: 108-110.

松井正春 (1992a) 小型ガラス室でのオンシツツヤコバチ放飼に よるトマトのタバココナジラミの防除. 関西病虫研報 34: $53-54$.

松井正春 (1992b) タバココナジラミの吸汁によるトマト果実の 着色異常. 応動昆 36: 47-49.

松井正春 (1993) タバココナジラミの最近における発生と防除. 植物防疫 47: 118-119.

松井正春・中島武彦 (1991) タバココナジラミとオンシッコナ ジラミの共存下におけるオンシッッヤコバチの寄主選好 性. 関西病虫研報 33: 93-94.

大泰司誠・岡田忠虎・刑部正博 (1992) タバココナジラミの新 系統と在来系統の生物的差異. 日本昆虫学会第 52 回大 会・第 36 回応動昆大会 p. 238 [講要〕.

大戸謙二 (1990) タバココナジラミの発生とその見分け方. 植
物防疫 44: 264-266.

Parrella, M.P., T.D. Paine, J.A. Bethie, K.L. Robb and J. Hall (1991) Evaluation of Encarsia formosa (Hymenoptera: Aphelinidae) for biological control of sweetpotato whitefly (Homoptera: Aleyrodidae) on poinsettia. Environ. Entomol. 20: $713-719$.

Perring, T.M., A.D. Cooper, R.J. Rodriguez, C.A. Farrar and T.S. BELlows, JR. (1993) Identification of a whitefly species by genomic and behavioral studies. Science 259: 74-77.

Price, J., D. Schuster and D. Short (1987) Controlling a new pest. Greenhouse Crower 12: 55-57.

西東 力・尾崎 丞(1991) タバココナジラミによって起こる トマト果実の着色異常. 農業及び園芸 66: 747-748.

Szabo, P., J.C. van Lenteren and P.W.T. Huisman (1993) Development time, survival and fecundity of Encarsia formosa on Bemisia tabaci and Trialeurodes vaporariorum. IOBC/WPRS Bull. 16(2): 173-176.

YANO, E. (1987) Control of the greenhouse whitefly, Trialeurodes vaporariorum Westwood (Homoptera: Aleyrodiae) by the integrated use of yellow sticky traps and the parasite Encarsia formosa Gahan (Hymenoptera: Aphelinidae). Appl. Entomol. Zool. 22: 159-165.

矢野栄三 (1988) オンシツコナジラミとその寄生蜂 Encarsia formosa GAHAN の個体群動態に関する研究. 野菜・茶業試験 場研究報告 A2: 143-200.

矢野栄二・腰原達雄 (1984) オンシッコナジラミ成虫の発生調 査法. 野菜試験場研究報告 A12: 85-96. 